\title{
Impacts to Myanmar with China-Myanmar Oil and Gas Pipeline Project
}

\author{
Yang Yang \\ International Business School \\ Yunnan University of Finance and Economics \\ Kunming, China \\ 1347789768@qq.com \\ Zhiyi Yin \\ International Business School \\ Yunnan University of Finance and Economics \\ Kunming, China \\ 1243114375@qq.com
}

\author{
Sen Lei \\ Business School \\ Yunnan University of Finance and Economics \\ Kunming, China \\ 28597081@qq.com \\ Xiaohong Cun* \\ International Business School \\ Yunnan University of Finance and Economics \\ Kunming, China \\ 16990822@qq.com
}

\begin{abstract}
In pace with their fast economic development, many countries energy needs keep getting more and more important. Because of its rich oil and gas resources, hydroelectric power, and mineral products, Myanmar's geographical position is seen as highly strategic. It has thus recently attracted growing attention from China, the United States, Canada, India and ASEAN countries.

China-Myanmar oil and gas pipeline project has been beneficial to both countries, but it still encountered considerable resistance. Cooperation between China and Myanmar also depends from other powers involved in Myanmar, which creates new challenges for China. More specifically, cooperation with China has already been impeded by ethnic conflicts in Myanmar, which always poses the risk of deferring those projects under construction . Furthermore, China also has to take into account the influence of other countries, such as the United States, India and ASEAN countries.
\end{abstract}

In sum, cooperation between Myanmar and China can bring benefits to both countries in politics and economic, but also in matters of societal development.

Keywords-China-Myanmar oil and gas pipeline project; Plight; Countermeasure

\section{INTRODUCTION}

China-Myanmar oil and gas pipeline project is the fourth largest energy imports channels after Central Asian oil and gas pipelines, Russia crude oil pipeline and Sea Lanes passage. It includes crude oil and gas pipelines that can transport crude oil from the southwestern region to China instead of being transported through the Strait of Malacca. 30th September, 2013, China-Myanmar gas pipeline opened up, started to transport gas to China; 30th January, 2015, China-Myanmar oil pipeline opened up, started to transport oil to China.

Myanmar is rich in oil and gas reserves, that is one of the world's first oil extraction. Myanmar currently has 34

\footnotetext{
* Corresponding author
}

pipelines, 19 offshore oil and gas fields and three oil and gas fields far from the sea, it has proven natural gas reserves of 2.54 trillion cubic meters, crude oil reserves of 32 billion barrels, ranking tenth in the world.

Myanmar and China have a long time good-neighborly relations in cooperation on energy projects began from the 1990s. In recent years, China's investment in Myanmar's oil and gas sector has continuously increase, Myanmar and China continue to deepen energy cooperation. The scope of cooperation include: mining, development and utilization of water resources and oil and gas exploitation.

\section{BENEFICIAL IMPACTS OF THE PROJECT}

China-Myanmar oil and gas pipeline project has a very important significance for both Myanmar and China.

First, from the view of political, the project ensured a stable political of Myanmar; second, after the pipeline put into operation its has a positive significance to promote the economic development of China and Myanmar; what's more, for the case of Myanmar, the introduction of pipeline project construction projects can increase local employment, and train related technicians.

\section{A. Political Significance}

1) International political interests

China-Myanmar oil and gas pipeline project funded by China, Myanmar, South Korea and India's six companies in four countries to carry out Natural gas pipeline. China Petroleum Group Southeast Asia Pipeline Company and Myanmar Oil and Natural Gas company cooperation to build Southeast Asia's oil pipeline. Crude-oil pipeline of China and Myanmar Oil pipeline project accounted for $51 \%$ of China National Petroleum Corporation and $49 \%$ for the Government of Myanmar [1].

First, Myanmar export oil and gas to neighboring countries that make Myanmar is expected to become Asia's major energy suppliers in the near future. To a certain extent, it 
guarantees the political security of Myanmar. Myanmar through China-Myanmar oil and gas pipeline project is closer to the relationship with China, the most powerful neighbor, and enhance its own security in geo-politics. All of this make sure Myanmar gain greater national interest. Strengthen energy cooperation with China, which result China's oil companies replace western oil companies' the status and role of the international cooperation project, and then maximize the ease to Western countries headed by the United States economic sanctions against Myanmar [2].

Secondly, the China-Myanmar oil and gas pipeline project can strengthen ties with the quartet of six-party, which can change the world situation that Myanmar has been over dependent on China since the 1990s. Myanmar implement balanced diplomacy for many countries to effectively protect the political security in Myanmar. China-Myanmar oil and gas pipeline project could rise Myanmar position in China's energy security strategy, and also enhanced China's energy dependence on Myanmar, thus Myanmar also will enhance the ability of game on China and Myanmar relations.

In addition, although Myanmar in Southeast Asia strategic location, rich resources, it has been unable to fully melt into the Southeast Asian country's economic development and political exchanges. It is through cooperation with China in various aspects, ASEAN countries have increasing emphasis on inclusion of Myanmar and bring it into ASEAN system. Therefore to carry out economic cooperation with China enhance geopolitical position for Myanmar has important significance.

\section{2) Domestic political interests}

Through launching active energy cooperation with China, Myanmar, the federal government can get help and support of the Chinese government, and thus stabilize the domestic political situation. Before Myanmar has been the country's long-ruling military, economic development low level, has been facing political democratization, people's livelihood, ethnic and other factors of instability. These problems often cause the turbulent political situation in Myanmar, which the national question is the most important. According to official statistics, Myanmar 135 ethnic divided into eight major ethnic groups who have their own national culture, national religion and national armed forces. There is conflict between centralization and interests of all ethnic groups often exist internal war; local armed forces and our nation's civil war junta Kachin, Karen, Kokang still exists. The expansion of their power and military equipment from the United States and other Western countries for their support and help [3]. In order to control their development, the federal government wants to with the help of Myanmar and Chinese foreign policy to seek political stability and economic development, and consolidate federal power.

\section{B. The Economic Significance}

\section{1) International economic interests}

Myanmar national energy cooperation can be roughly divided into three categories, the first category is the West countries, the second is India and Southeast Asian countries, China is the third category. First, Myanmar and Western countries in developing energy and mining industry in the process of cooperation, since long before the US policy of isolation and sanctions, leading Western countries in Myanmar Investment projects are often not properly maintained, its capital and technology cooperation is strictly limited, resulting in Myanmar to cooperate with Western countries they are often unable to obtain the expected benefits and costs tremendous time. And the same in Myanmar States to carry out the economic benefits of high oil and gas resources cooperation received, and quick, which is unmatched in Western countries [4].

Comprehensive comparison, Myanmar in the process of cooperation with China can often obtain the expected economic benefits, and Chinese abundant capital and advanced technology for Myanmar's economic development has an important impetus for pushing. In 2014, Myanmar as ASEAN's rotating presidency of the summit, through the successful completion of the China-Myanmar oil and gas pipelines project and Stable operation greatly promote China ASEAN economic relations deepen, has become a prosperous economic corridor and the China - ASEAN.

\section{2) Domestic economic interests}

After the completion of the pipeline operations, as one of the shareholders of the pipeline in Myanmar in addition to stable income, but also get huge transit fees and maintenance costs every year.

In addition, the natural gas will be transported to the inland coastal area of Magway Province, Mandalay Province, through the pipeline, not only can promote the economic development of these areas, can also bring development along the pipeline opportunity.

On the one hand, according to the agreement ChinaMyanmar oil and gas pipelines, Myanmar can share $20 \%$ of the share of natural gas and 200 Tons of crude oil, which could alleviate the shortage of oil and gas in Myanmar. Myanmar supply 12 billion cubic meters of natural gas for China every year will increase to 24 billion cubic meters in 2019, at the same time China will become the largest and most stable Myanmar buyer. In addition, the China-Myanmar oil and gas pipeline companies pay to Myanmar transit costs \$ 150 million every year, according to the pipeline contract 20-30 year period it can get as much as Myanmar 30-45 billion dollars in transit fees, the China-Myanmar oil and gas pipeline project will become Myanmar long-term stable financial source of income [5].

On the other hand, operating the China-Myanmar oil and gas pipelines in the energy security of the oil and natural gas export scale and stability in Myanmar, to ensure that export oil and gas fields in Myanmar's oil and gas production, breaking the Myanmar gas exports rely on the Thai market dilemma, which has great significance to reduce the risk of natural gas export in Myanmar.

Secretary-General of the Myanmar Business Association Kaikai within predicted that the next 20 years, the average annual economic growth up to Myanmar7\% to $8 \%$. Thus, Myanmar can fully develop the oil and gas as a lever to revitalize the country's economy [6]. 


\section{The Social Significance}

China-Burma gas pipeline project in the whole peak construction period of employment of local staff in Myanmar to reach more than 6,000 people, more than $60 \%$ of the total personnel participating in the construction of Myanmar, Myanmar workers not only get a steady income, but also learned a technique, has laid a foundation for future development. As the project progresses, the company will further enhance the localization of staff, Myanmar actively training staff, so his skill level and overall quality continues to improve, and to create more employment opportunities for local people in future projects and pipeline operations so that they can learn advanced technology and management expertise. In order to protect the pipeline operations, the company launched the villagers along the employment programs will employ hundreds of skilled workers involved in the daily operations of the Myanmar pipeline after the completion of the first batch of more than 60 Burmese workers have been organized to go to Southwest Petroleum University study, many of which are residents along the pipeline.

China-Myanmar oil and gas pipeline company also pledged to increase investment in local communities, it allocated \$200 million per year for corporate social responsibility project development. From the economic point of view of energy, oil and gas pipeline construction has a "spillover effect", not only can promote economic development through the construction of the pipeline along the pipeline, and promote the process of urbanization along the pipeline, and then pull the overall economic development of Myanmar, but also can bring downstream oil refining, transportation and marketing of industrial development. According to the agreement between China and Myanmar, China will be 5.6 million barrels per day refinery in aid Mandalay, Myanmar, to ease the domestic oil supply and demand [7].

\section{UNFAVORABLE FACTORS IN THE PROJECT}

\section{A. Adverse Public Opinion}

At the beginning of this project, it was suffered the Myanmar non-governmental organizations (NGO) and local residents strongly opposed. These people opposed the project, and accused China and Myanmar oil and gas pipeline projects has undermined the Burmese rights in land acquisition, environmental destruction, forced migration, and the military aspects of labor. The evidences they provided has strongly inductivity, in the absence of clarification and refute from the Chinese authorities, these adverse reports had a very bad influence in the international community.

\section{B. Malacca Dilemma}

The Malacca dilemma refers to China's lifeline in the Malacca Strait in the event of accidents at sea, will pose a great risk to China's energy security, and threatened China's national security.

In the eyes of many people, the China and Myanmar oil and gas pipeline projects shoulder the task to relieve Malacca dilemma. China has invested heavily in a strategic mind in order to energy security, expand geopolitical influence. However, if the in-depth understanding of the socio-political situation in Myanmar and its development trend, examining the overall pattern of Chinese imports of oil and gas sources and transportation in detail, and oil and gas processing capacity in southwest China, pipeline construction and other factors, it is difficult to find China and Myanmar oil and gas pipelines played a negligible role for cracking "Malacca dilemma", 22 million tons of oil is tantamount to drop in the bucket.

\section{COUNTERMEASURE}

\section{A. Promotion of Inter-governmental Relations}

From the domestic adverse opinion of view, most of Myanmar's protest was not against China, they were mainly opposed to the Junta. The junta not published contents of projects, lack of policy transparency.

Therefore, to ensure long-term cooperation on energy between China and Myanmar, China should set up a special department responsible for public relations companies in the local image maintenance, during the execution of the project. It should also be ongoing assessments to ensure that local people benefit from the project to make sure and satisfaction.

In addition to the initiative of the masses along the pipeline in Myanmar to build roads, schools, hospitals and other infrastructure, to increase awareness of local residents of Chinese enterprises and projects, but also the need for the measures the government of Myanmar to dispose of individual rights related to mass taken to give high degree of attention, and to provide appropriate employment compensation and other benefits to compensate for the local neighborhoods, such as the occupation of land or migrate certain compensation for loss caused so on [8].

\section{B. Establishment of Mechanisms for Energy Cooperation}

With the increasing complexity of the international energy situation, the world's attention to the country's energy security has become increasingly prominent, and security the implementation of national energy policy of national energy security in countries, the inevitable conflicts of interest relating to energy will occur [9].

China should establish mechanisms for regional energy cooperation and realize win-win, rather than mutual hostility and conflict. In addition to relying on the China and Myanmar oil and gas pipeline projects for our energy supplies, the most important thing is to establish energy cooperation with neighboring countries mechanisms to enable diversification of energy imports, which largely secure the future of our country's energy security.

\section{CONCLUSIONS}

China-Myanmar cooperation from a global point of view, there is great significance to build and operate oil and gas pipeline project between China and Myanmar.

From the perspective of Myanmar, the pipeline putting into operation not only to enhance the ability of the political status of the game and Myanmar, but also greatly boost the economic development of Myanmar. From China's perspective, the biggest impact is provides a more secure energy channels--the two oil and gas pipelines --to China but also help protect the security of the southwest portal. 
Although there are a lot of positive impact, but we can't ignore the disadvantages that between the two countries' cooperation. Myanmar domestic political was instability, economic reform has not been completed, the western powers and unwarranted intervention tricky Malacca dilemma cooperation issues between the two countries gave an enormous challenge. For long-term cooperation between China and Myanmar and China's energy security, China should adopt a positive attitude to deal with the difficulties faced by the government in promoting the relations between two countries, China should also strengthen non-governmental exchanges, to provide a stable operation environment of the China-Myanmar oil and gas pipeline project, the last and most important thing is the implementation of energy import diversification strategy to protect China's energy security.

\section{ACKNOWLEDGMENT}

I would like to extend my sincere gratitude to my supervisor, Xiaohong Cun, for his instructive advice and useful suggestions on my thesis. I am deeply grateful of his help in the completion of this thesis. I am also deeply indebted to all the other tutors and teachers in International Business School of YNUFE for their direct and indirect help to me. Special thanks should go to my friends who have put considerable time and effort into their comments on the draft.
Finally, I am indebted to my parents for their continuous support and encouragement.

\section{REFERENCES}

[1] H. Yin, "The Impact on the China-Burma Pipeline Project in Southeast Asia and the Southwest Region of China," China Science and Technology Information, 2012.

[2] G.Y. Sun, "New Power Development in Myanmar," People's Daily, 2013.

[3] Nene Egypt, "Energy Cooperation between Myanmar and China: From a Myanmar," Shandong University, 2014.

[4] X.G. Zhu, "Changes in the Situation in Myanmar on the China-Burma oil and gas pipeline safety and Countermeasures," Kunming Institute reported, 2014.

[5] Y. Li, Y. Wang, and Y. Yang, "China-Burma Pipelines Distressed," Finance magazine, 2013.

[6] G.S. Lu, "China under Kim Jin Myanmar Political and Economic Transition Background Myanmar Investment," South Asian Studies, 2013.

[7] X.L. Ma, "China-Burma Oil and Gas Pipelines: Both Strategic and Specimens Significance," China Times, 2015.

[8] G.H. Feng, "Political Game Behind the Chinese Transnational Oil and Gas Pipelines," China University of Petroleum, 2011.

[9] B. Liu, "Geopolitical Perspective energy cooperation between China and Myanmar," Shandong University, 2012. 